\title{
Comparison of some anatomical, chemical and fibrous characteristics of Turkish Red Pine (Pinus brutia Ten.) sampled from different regions
}

\author{
Mabrouka Mohamed Muftah ABUAMOUD, Saim ATES, Ekrem DURMAZ* \\ Kastamonu University, Faculty of Forestry, Kastamonu, TURKEY \\ *Corresponding author: edurmaz@kastamonu.edu.tr
}

Received Date: 11.12 .2017

Accepted Date: 26.02 .2018

\section{Abstract}

Aim of study: In this study, it was aimed to research the anatomical properties, chemical composition of the cell wall and fiber characteristics of Turkish Red Pine (Pinus brutia Ten.) wood sampled from five different zone of Kastamonu province in Turkey.

Area of study: This study was performed at the laboratories of Department of Forest Industry Engineering and Department of Biology, Kastamonu University.

Material and Methods: Turkish Red Pine (Pinus brutia Ten.) wood samples obtained from Hanönü, Bozkurt, Araç, İnebolu and Tosya were used as experimental materials. Anatomical properties, chemical structure of wood and fibrous characteristics of wood fibers were determined according to standard methods.

Main results: This study indicated that Tosya samples had maximum fibre length with $3.15 \mathrm{~mm}$ and maximum lumen width with $27.75 \mu \mathrm{m}$, whereas maximum fibre width was found in İnebolu samples with $42.27 \mu \mathrm{m}$ and maximum cell wall thickness was seen in samples of İnebolu with $7.90 \mu \mathrm{m}$. As a consequence of chemical analyses, it was confirmed that holocellulose, alpha-cellulose and lignin ratios, $1 \% \mathrm{NaOH}$, ethanol, hot water and cold water solubilities and ash ratio changed within the range of 70.37-72.38, 42.62-47.30, 26.04-27.86, 12.38-13.14, 2.38-3.41, 2.86-3.83, 2.29-3.27 and 0.26-0.40 as percent respectively. In the results of anatomical research, it was seen that Hanönü samples had maximum average ray numbers with 7. Likewise, maximum tracheid widths were found samples in İnebolu and Bozkurt with $1.31 \mu \mathrm{m}$. Besides, maximum earlywood width was confirmed Bozkurt samples with $0.47 \mathrm{~mm}$, whereas maximum latewood width was confirmed Hanönü samples with $1.31 \mathrm{~mm}$.

Research highlights: It is inferred that the same tree species taken from different areas have varied anatomical, chemical and fibre properties measured by means of this study. Because of this, it can be stated that growth location properties and growth media affect the characteristics of same type trees.

Keywords: Turkish Red Pine, Anatomical Properties, Wood Chemical Components, Wood Fibre Characteristics

\section{Farklı bölgelerden alınan Kızılçam (Pinus brutia Ten.) odunlarının}

\section{bazı anatomik, kimyasal ve lifsel özelliklerinin karşılaştırılması}

\section{Özet}

Çalışmanın amacı: Bu çalışmada Kastamonu ilinin beş farklı bölgesinden temin edilen kızılçam (Pinus brutia Ten.) odunu örneklerinin anatomik özellikleri, hücre çeperi kimyasal bileşenleri ve lifsel özelliklerinin araştırılması amaçlanmıştır.

Çalışma alanı: Bu çalışma, Kastamonu Üniversitesi Orman Endüstri Mühendisliği Bölümü ve Biyoloji Bölümü laboratuvarlarında gerçekleştirilmiştir.

Materyal ve Yöntem: Deney materyali olarak Hanönü, Bozkurt, Araç, İnebolu and Tosya bölgelerinden alınan Kızılçam (Pinus brutia Ten.) odunu örnekleri kullanılmıştır. Anatomik özellikler, odunun kimyasal yapısı ve lifsel özellikler standart yöntemlere göre tespit edilmiştir.

Sonuçlar: Bu çalışma, Tosya örneklerinin $3.15 \mathrm{~mm}$ ile en yüksek lif uzunluğuna ve $27.75 \mu \mathrm{m}$ ile en yüksek lümen genişliğine sahip olduğu, İnebolu örneklerinin ise $42.27 \mu \mathrm{m}$ ile maksimum lif genişliğine ve $7.90 \mu \mathrm{m}$ ile maksimum hücre çeperi kalınlığına sahip olduğunu ortaya koymuştur. Kimyasal analizlerin sonucunda, holoselüloz, alfa selüloz ve lignin oranları, \%1 NaOH, etanol, sıcak su ve soğuk su çözünürlükleri ile kül oranının yüzde olarak sirasiyla 70.37-72.38, 42.62-47.30, 26.04-27.86, 12.38-13.14, 2.38-3.41, 2.86-3.83, 2.29-3.27 ve 0.26-0.40 arasinda değiştiği belirlenmiştir. Anatomik araştırmaların sonuçlarında, Hanönü örneklerinin en yüksek öz ışını sayısına (ort. 7) sahip olduğu görülmüştür. Benzer şekilde maksimum traheid genişliği İnebolu ve Bozkurt örneklerinde $1.31 \mu \mathrm{m}$ olarak tespit edilmiştir. Ayrıca maksimum ilkbahar odunu genişliği $0.47 \mathrm{~mm}$ olarak Bozkurt örneklerinde bulunmuşken, maksimum yaz odunu genişliği $1.31 \mathrm{~mm}$ ile Hanönü örneklerinde bulunmuştur.

Araştırma vurguları: Bu çalışma ile farklı bölgelerden alınan benzer ağaç türlerinin farklı anatomik, kimyasal ve lifsel özelliklere sahip olduğu sonucuna varılmaktadır. Bundan dolayı yetişme yeri özelliklerinin ve büyüme ortamlarının benzer türdeki ağaçların özelliklerini etkilediği söylenebilir.

Anahtar Kelimeler: Kızılçam, Anatomik Özellikler, Odun Kimyasal Bileşenleri, Odun Lif Özellikleri 


\section{Introduction}

Turkish Red Pine forests spreading area reaches nearly 5.6 million ha in Turkey. In general, Turkish Red Pine (Pinus brutia Ten.) spreads Turkey, Crete, Cyprus, Syria, Israel and Lebanon, but it exists in Iraq and Iran in small quantities (Fady et al., 2011; Praciak, 2013; Tutus et al., 2017). The nature spreading of Turkish Red Pine (Pinus brutia Ten.) occurs the zones between 15-45. east longitudes and 32-45. north latitudes of North hemisphere. Because especially it spreads in Mediterranean Region and Anatolia, it adopted as a type of East Mediterranean (Neyisci, 2001).

Turkish Red Pine (Pinus brutia Ten.) spreads in Turkey in the largest form. Generally, it exists in Marmara, Aegean and Mediterranean regions notwithstanding that it spreads in Blacksea coasts as small groups (Neyisci, 2001). Until today, four varieties of Pinus brutia subsp. brutia were found (Papajoannou, 1936; Selik, 1962; Frankis, 1993; Yaltırık and Boydak, 1989, 2000; Schiller, 2000).

Turkish Red Pine grows coastal regions and it reaches $15-20 \mathrm{~m}$ length and $60 \mathrm{~cm}$ diameter (Ansin and Özkan, 2006). Their stems aren't smooth in general, but it is seen that the stems of trees start to become smooth as altitude rise and their lengths increase. Furthermore, their tops taper and their branches are slim (Yaltırik and Efe, 2000). The branches, which form a broadly conical and dome-shaped crown, flatten and open as the tree ages (Chambel et al., 2013). Juvenile shoots are thick and dark red. The needles are nearly $10-16 \mathrm{~cm}$, but sometimes they reach to $20 \mathrm{~cm}$ and they are thick and dark green. The needle anatomy of Turkish Red Pine is different from Aleppo Pine's (Göksin, 2001; Praciak, 2013).

Nowadays, Turkish Red Pine woods are used in sidings, woodworking industry, production of traverses, panel, packing case, mine timber, telegraph pole, furniture, agricultural instruments etc. comprehensively
(Bozkurt, 1971; Kayac1k, 1980; Ansin and Özkan, 2006; Gürboy, 2007). Turkish Red Pine wood is thought as a significant raw material in pulp and paper production as well as barks of it are utilized in tannin production (Erten and Taşkın, 1985; Gürboy, 2007). In addition to these, Turkish Red Pine is one of the preeminent types in resin production and also it appraises in afforestation of arid lands (Ansin and Özkan, 2006).

Within the context of this study the anatomic, fibrous and chemical properties of wood samples of Pinus brutia samples taken from five different zones in Kastamonu, Turkey (Hanönü, Araç, Bozkurt, İnebolu and Tosya) were studied and compared.

\section{Material and Method \\ Material}

In this study, wood samples of Turkish Red Pine (Pinus brutia Ten.) supplied from five different zones in Kastamonu (Hanönü, Araç, Bozkurt, İnebolu and Tosya) were used. The wood samples were obtained 1.30 $\mathrm{m}$ above ground level and they were cut as wheels with $10 \mathrm{~cm}$ thick. All of the samples were dried in the room temperature. The wood samples were prepared for each experiment and analyse separately. For the analyses, it was utilised from laboratories of Department of Forest Industry Engineering and Department of Biology, Kastamonu University. In Table 1 and Table 2, altitudes and aspects of work areas as well as general informations about work areas (average values) were shown, respectively.

Table 1. Altitudes and aspects of work areas (Average values)

\begin{tabular}{ccc}
\hline Work Areas & Altitude $(\mathbf{m})$ & Aspect \\
\hline Hanönü & 450 & North \\
\hline Araç & 850 & South \\
\hline Bozkurt & 60 & West \\
\hline İnebolu & 80 & West \\
\hline Tosya & 500 & North \\
\hline
\end{tabular}


Table 2. General informations about work areas (Average values) (URL-1)

\begin{tabular}{cccc}
\hline Work Areas & Relative humidity $(\boldsymbol{\%})$ & Temperature $\left({ }^{\mathbf{0}} \mathbf{C}\right)$ & Precipitation $(\mathbf{m m})$ \\
\hline Hanönü & 48.3 & 11.8 & 832.5 \\
\hline Araç & 57.7 & 10.6 & 450.1 \\
\hline Bozkurt & 79.2 & 13.5 & 1136.2 \\
\hline İnebolu & 75.2 & 13.2 & 999.5 \\
\hline Tosya & 62.4 & 11.5 & 353.1 \\
\hline
\end{tabular}

\section{Method}

\section{Determination of Fibrous Properties}

In determination of fibrous properties of Turkish Red Pine (Pinus brutia Ten.) it was utilised from maceration method of Mahesh et al. (2015). Wood samples taken from each zone were cut in the shape of matchstick. Chopped wood samples were submerged in $37 \%$ formaldehyde solution and was waited during a night. Before the maceration, treated samples were washed with distilled water and filtered to avoid more evaporation of formaldehyde. The concentration of nitric acid used in maceration process was arranged as $50 \%$. Wood samples were put in the beakers with nitric acid and sunk completely. The beakers were put in a water bath at $70^{\circ} \mathrm{C}$. Maceration treatment was continued 5-6 hours until the samples completely bleached. The beakers were taken out from water bath and they were cooled under ambient conditions. After that, acid solutions were drained and macerated samples were washed plenty of distilled water.

Safranin was prepared for microscopic observations. Then fibrous were sampled from solution with a dropper and put on the glass slide.

The measurements of fibres were conducted with a light microscope and 100 measurements from each sample were performed for determination of fibre lengths, fibre widths, lumen widths and cell wall thicknesses. The measurements were done in a Digimizer ${ }^{\circledR}$ programme (MedCalc Software bvba, Belgium).

\section{Determination of Chemical Properties}

Chemical analyses of all wood samples were performed according to TAPPI standards for determination of main wood components. Before the chemical analyses, wood samples were grinded in a Wiley Mill and samples were prepared according to TAPPI T $257 \mathrm{~cm}-85$ standard. All of the analyses were repeated three times to provide consistency. Following experiments were done for the wood samples according to related standards (Hafızoğlu and Deniz, 2011; URL-2).

- Ethanol solubility (TAPPI T 204 om-88)

- Holocellulose determination (Chlorite method of Wise)

- Alpha-cellulose determination: TAPPI T 203 OS-71

- Lignin determination: TAPPI T 222 om88

- Cold and hot water solubility: TAPPI T 207 om-88

- $1 \% \mathrm{NaOH}$ solubility: TAPPI T 212 om88

- Ash determination: TAPPI T 211 om-85

\section{Determination of Anatomical Properties}

Wood samples gotten from five different regions were cut as $20 \times 20 \times 20 \mathrm{~mm}$ as cubic blocks. Then the blocks were boiled in a hot water bath 6 hours/day during 5 days. Sliced samples were taken from three anatomical section (radial, cross and tangential) of the cubes by using a Thermo Shandon Finesse 325 microtome and the slides were prepared according to international standards. The images were analysed with a Leica DM3000 light microscope.

\section{Results and Discussion Fibrous Analyses}

In this chapter the fibres of all of the wood samples were observed with light microscope and fibre characteristics (fibre length, fibre width, lumen width and cell wall thickness) were determined with a software (Digimizer). The fibre dimensions of samples were given in Table 3. 
Table 3. The fibre dimensions of wood samples

\begin{tabular}{lcccccccc}
\hline Zone & $\begin{array}{c}\text { Fibre } \\
\text { length } \\
(\mathbf{m m})\end{array}$ & S.D & $\begin{array}{c}\text { Fibre } \\
\text { width } \\
(\boldsymbol{\mu \mathbf { m } )})\end{array}$ & S.D & $\begin{array}{c}\text { Lumen } \\
\text { width }(\boldsymbol{\mu m})\end{array}$ & S.D & $\begin{array}{c}\text { Cell wall } \\
\text { thickness } \\
(\boldsymbol{\mu \mathbf { m } )})\end{array}$ & S.D \\
\hline Hanönü & 2.05 & 0.86 & 40.57 & 2.51 & 26.93 & 2.71 & 6.74 & 1.16 \\
\hline Bozkurt & 1.86 & 1.86 & 41.03 & 2.95 & 26.95 & 2.49 & 6.96 & 1.36 \\
\hline Araç & 2.22 & 2.22 & 41.97 & 3.35 & 26.71 & 3.39 & 7.61 & 1.46 \\
\hline Inebolu & 2.21 & 2.21 & 42.27 & 3.85 & 26.32 & 3.57 & 7.90 & 1.79 \\
\hline Tosya & 3.15 & 3.15 & 41.90 & 3.24 & 27.75 & 4.27 & 7.20 & 1.38 \\
\hline
\end{tabular}

S.D.: Standard Deviation

According to Table 3, the highest fibre length was determined in samples in Tosya with $3.15 \mathrm{~mm}$, whereas the highest fibre width was determined in samples in İnebolu with $42.27 \mu \mathrm{m}$. It was seen that the maximum value was obtained for lumen width in samples in Tosya with $27.75 \mu \mathrm{m}$ and the maximum value was obtained for cell wall thickness in samples in İnebolu with $7.90 \mu \mathrm{m}$.

In the literature there are many studies about fibrous characteristics of Turkish Red Pine and the other types. Göksel (1981) and Tank et al. (1990) determined fibre lengths as $4.27-4.70 \mathrm{~mm}$ and $3.20 \mathrm{~mm}$; fibre widths as 47.85-49.11 $\mu \mathrm{m}$ and $25.05 \mu \mathrm{m}$; lumen widths as $28.14-30.34 \mu \mathrm{m}$ and $15.49 \mu \mathrm{m}$; cell wall thicknesses as $8.99-9.77 \mu \mathrm{m}$ and $4.78 \mu \mathrm{m}$ of Turkish Red Pine wood samples, respectively. Bektas et al. (1999) found fibre length as $4.42 \mathrm{~mm}$; fibre width as $40.40 \mu \mathrm{m}$; lumen width as $25.09 \mu \mathrm{m}$ and cell wall thickness as $7.03 \mu \mathrm{m}$ of Turkish Red Pine. Gürboy (2007) confirmed fibre length as 2.71-3.02 $\mathrm{mm}$; fibre width as 51.87-54.04 $\mu \mathrm{m}$; lumen width as 34.35-39.59 $\mu \mathrm{m}$ and cell wall thickness as 6.43-9.28 $\mu \mathrm{m}$ in his study about Turkish Red Pine. Similarly, in a study related to Turkish Red Pine Saruusta (2007) determined fibre length as $4.14 \mathrm{~mm}$; fibre width as $42.5 \mu \mathrm{m}$; lumen width as $28.35 \mu \mathrm{m}$ and cell wall thickness as $14.15 \mu \mathrm{m}$.

\section{Chemical Analyses}

Under this title the chemical components of Turkish Red Pine wood samples were determined. Within this framework ethanol solubility value, holocellulose ratio, alphacellulose ratio, lignin ratio, cold and hot water solubility value, $1 \% \mathrm{NaOH}$ solubility value and ash ratio of wood samples were calculated with TAPPI standards. The results of chemical analyses were given in Table 4 .

Table 4. The chemical components of wood samples

\begin{tabular}{lccccc}
\hline Analyses (\%) & Tosya & Hanönü & İnebolu & Bozkurt & Araç \\
\hline Ethanol solubility & 2.54 & 2.38 & 2.44 & 3.08 & 3.41 \\
\hline Lignin ratio & 26.89 & 26.47 & 27.09 & 27.86 & 26.04 \\
\hline Holocellulose ratio & 71.94 & 72.38 & 71.81 & 70.37 & 70.44 \\
\hline Alpha-cellulose ratio & 47.30 & 42.62 & 43.76 & 47.19 & 46.38 \\
\hline 1\% NaOH solubility & 12.38 & 12.47 & 13.05 & 13.14 & 12.53 \\
\hline Cold water solubility & 3.27 & 2.49 & 2.32 & 3.11 & 2.29 \\
\hline Hot water solubility & 3.83 & 3.44 & 2.93 & 2.86 & 3.10 \\
\hline Ash ratio & 0.36 & 0.40 & 0.28 & 0.37 & 0.26 \\
\hline
\end{tabular}

When Table 4 was researched, it was seen that the highest values were determined as $3.41 \%$ in Araç for ethanol solubility; $27.86 \%$ in Bozkurt for lignin ratio; $72.38 \%$ in Hanönü for holocellulose ratio; $47.30 \%$ in Tosya for alpha-cellulose ratio; $13.14 \%$ in Bozkurt for $1 \% \mathrm{NaOH}$ solubility; $3.27 \%$ in
Tosya for cold water solubility; $3.83 \%$ in Tosya for hot water solubility and $0.40 \%$ in Hanönü for ash ratio.

In previous studies same results were obtained with Turkish Red Pine wood samples. Tank et al. (1990) confirmed as $65.46 \%$ for holocellulose ratio; $27.47 \%$ for 
lignin ratio; $42.55 \%$ for alpha-cellulose ratio; $5.04 \%$ for hot water solubility; $11.70 \%$ for $1 \% \mathrm{NaOH}$ solubility; $7.92 \%$ for alcoholbenzene solubility; $5.10 \%$ for ether solubility; $10.00 \%$ for pentosan and $0.47 \%$ for ash ratio in their studies. Kirc1 (1991) found as $70.8 \%$ for holocellulose ratio; $27.4 \%$ for lignin ratio; $54.1 \%$ for cellulose ratio; $5.0 \%$ for hot water solubility; $8.5 \%$ for $1 \% \mathrm{NaOH}$ solubility; $5.8 \%$ for alcoholbenzene solubility and $0.37 \%$ for ash ratio. In another study Hafizoğlu and Usta (2005) determined as $28 \%$ lignin ratio in heartwood and as $29 \%$ lignin ratio in sapwood; as $52.6 \%$ cellulose ratio in heartwood and as $57.9 \%$ cellulose ratio in sapwood; as $45.2 \%$ alpha-cellulose ratio in heartwood and as $50.2 \%$ alpha-cellulose ratio in sapwood. Besides, they found cold and hot water solubility, alcohol-benzene solubility and 1\%
$\mathrm{NaOH}$ solubility values for heartwood and sapwood as $3.1-2.4 \% ; 6.5-5.1 \% ; 7.6-5.7 \%$ and $10.2-9.1 \%$ respectively. Baharoglu et al. (2013) confirmed as $71.68 \%$ for holocellulose ratio; $52.64 \%$ for cellulose ratio; $45.68 \%$ for alpha-cellulose ratio; $25.98 \%$ for lignin ratio; $5.62 \%$ for hot water solubility; $16.05 \%$ for $1 \% \mathrm{NaOH}$ solubility and $5.18 \%$ for alcohol-benzene solubility in their study.

\section{Anatomic Analyses}

In this chapter microscopic investigations of Turkish Red Pine wood samples were conducted for determination of anatomic characteristics. In Figure 1 microscopic images of wood samples in radial, tangential and cross sections were shown. In addition, it was indicated the anatomical properties of wood samples in Table 5.



Figure 1. The microscopic images of wood samples in a) radial b) tangential c) cross sections

Table 5. The anatomical properties of wood samples

\begin{tabular}{lccccccc}
\hline Zone & $\begin{array}{c}\text { Ray numbers } \\
(\text { Mean) }\end{array}$ & $\begin{array}{c}\text { Tracheid } \\
\text { width } \\
(\boldsymbol{\mu m})\end{array}$ & S.D & $\begin{array}{c}\text { Earlywood } \\
\text { width }(\mathbf{m m})\end{array}$ & S.D & $\begin{array}{c}\text { Latewood } \\
\text { width } \\
(\mathbf{m m})\end{array}$ & S.D \\
\hline Araç & $4-9(6.5)$ & 1.29 & 0.18 & 0.32 & 0.10 & 1.21 & 0.17 \\
\hline Tosya & $3-10(6.5)$ & 1.30 & 0.13 & 0.19 & 0.22 & 1.18 & 0.11 \\
\hline Bozkurt & $2-8(5)$ & 1.31 & 0.12 & 0.47 & 0.07 & 1.15 & 0.12 \\
\hline Hanönü & $3-11(7)$ & 1.29 & 0.20 & 0.35 & 0.14 & 1.31 & 0.19 \\
\hline İnebolu & $5-8(6.5)$ & 1.31 & 0.18 & 0.40 & 0.09 & 1.21 & 0.17 \\
\hline
\end{tabular}

S.D.: Standard Deviation

According to Table 5, the highest average ray numbers were obtained samples taken from Hanönü zone with 7 . The highest tracheid widths were determined samples in
Bozkurt and İnebolu with $1.31 \mu \mathrm{m}$. In addition, maximum earlywood width was seen samples taken from Bozkurt with 0.47 $\mathrm{mm}$, while maximum latewood width was 
seen samples taken from Hanönü with 1.31 $\mathrm{mm}$.

The results in the literature shows similarities with results in this study. For instance, Ay (1993) was found as $37.5 \mu \mathrm{m}$ in tangential section, as $25.53 \mu \mathrm{m}$ in radial section tracheid diameters of Turkish Red Pine earlywood and as 273 tracheid number in $1 \mathrm{~mm}^{2}$ in earlywood, as 482 tracheid number in $1 \mathrm{~mm}^{2}$ in latewood. Besides in this study, tracheid length was found as $3.23 \mathrm{~mm}$ in earlywood and as $3.8 \mathrm{~mm}$ in latewood, whereas tracheid width was found as 45.16 $\mu \mathrm{m}$ in earlywood and as $40.05 \mu \mathrm{m}$ in latewood. They confirmed cell wall thickness as $4.70 \mu \mathrm{m}$ and as $7.52 \mu \mathrm{m}$ in earlywood and latewood, respectively. In another study, Bozkurt et al. (1993) determined as $3.09 \mathrm{~mm}$ average tracheid length and as $40 \mu \mathrm{m}$ average tracheid width in Turkish Red Pine wood samples. They found ray number as 1-26 in tangential section.

\section{Conclusion}

Within the context of this study anatomic, fibrous and chemical characteristics of Turkish Red Pine (Pinus brutia Ten.) wood samples taken from five different zones (Tosya, Hanönü, İnebolu, Bozkurt and Araç) in Kastamonu were investigated. According to obtained results, it was seen that the samples taken from varied zones had varied wood properties. According to results of fibrous analyses, fibre lengths were between $1.86 \mathrm{~mm}-3.15 \mathrm{~mm}$; fibre widths were 40.57 $\mu \mathrm{m}-42.27 \mu \mathrm{m}$; lumen widths were $26.32 \mu \mathrm{m}$ $27.75 \mu \mathrm{m}$ and cell wall thicknesses were 6.74 $\mu \mathrm{m}-7.90 \mu \mathrm{m}$. As a result of chemical analyses, it was determined that ethanol solubility, lignin ratio, holocellulose ratio, alpha-cellulose ratio, $1 \% \mathrm{NaOH}$ solubility, cold water solubility, hot water solubility and ash ratio changed between $2.38 \%-3.41 \%$; 26.04\%-27.86\%; 70.37\%-72.38\%; 42.62\%$47.30 \% ; \quad 12.38 \%-13.14 \% ; \quad 2.29 \%-3.27 \%$; $2.86 \%-3.83 \%$ and $0.26 \%-0.40 \%$, respectively. When microscopic analyses were investigated, it was found that ray numbers were within the range of 5-7; tracheid widths were between $1.29 \mu \mathrm{m}-1.31$ $\mu \mathrm{m}$; earlywood widths were between 0.19 $\mathrm{mm}-0.47 \mathrm{~mm}$ and latewood widths were within the range of $1.15 \mathrm{~mm}-1.31 \mathrm{~mm}$.
As a consequence, it was seen that the characteristics of same kind of wood samples taken from different zones may change with regards to climate, precipitation, soil properties etc. with fibrous, chemical and anatomic analyses. Likewise, all of these characteristics may change in different zones (branch, stem, root etc.) of same tree. By looking at the obtained characteristics, it can be decided end-use place of tree types in the industry.

\section{Acknowledgments}

The technical supports of this study were provided by laboratories of Department of Forest Industry Engineering and Department of Biology in Kastamonu University.

\section{References}

Ansin, R., Özkan, Z.C. (2006). Tohumlu bitkiler (Spermatophyta) odunsu taksonlar, Yayın No: 19/167, Karadeniz Teknik Üniversitesi Basımevi, Trabzon.

Ay, N. (1993). Alanya yöresi kızılçamlarının iç morfolojik özelliklerinin incelenmesi, Uluslararası Kızılçam Sempozyumu Bildiriler Kitab1, 662-669.

Baharoglu, M., Nemli, G., Sarı, B., Birtürk, T. Bardak, S. (2013). Effects of anatomical and chemical properties of wood on the quality of particleboard, Composites: Part B, 52, 282-285.

Bozkurt, Y. (1971). Önemli bazı ağaç türlerinin tanımı, teknolojik özellikleri ve kullanılış yerleri. İstanbul Üniversitesi Orman Fakültesi Dergisi, 177. İstanbul.

Bozkurt, Y., Göker, Y., Erdin, N,. As, N. (1993). Datça kızılçamında anatomik ve teknolojik özellikler, Uluslararası Kızılçam Sempozyumu Bildiriler Kitabı, 628-635.

Bektas, İ., Tutus, A., Eroglu, H. (1999). A study of the suitability of Calabrian Pine (Pinus brutia Ten.) for pulp and paper manufacture. Turkish Journal of Agriculture and Forestry. Ek say1 3(23), 589-597.

Chambel, M. R., Climent, J., Pichot, C., Ducci, F. (2013). Forest tree breeding in Europe, Managing Forest Ecosystems, 25, 229-265.

Erten, P., Taskın, O. (1985). Kızılçam (Pinus brutia Ten.) kabuklarında tanen 
miktarının saptanmasına ilişkin araştırmalar. Ormancılı Araştırma Enstitüsü Yayınları. Teknik Bülten Serisi, No. 147.

Fady, B., Semerci, H., Vendramin, G. G. (2011). Euforgen technical guidelines for genetic conservation and use for Aleppo pine (Pinus halepensis) and Brutia pine (Pinus brutia), Bioversity International, 16.

Frankis, I. (1993). Morphology and affinities of Pinus brutia Ten. Proceedings of the International Symposium of Pinus brutia Ten. Marmaris, Turkey, 11-18, Publication of Ministry of Forestry, Ankara.

Göksel E. (1981). Kızılçamın lif morfolojisi ve odunundan sülfat selülozu elde etme olanakları üzerine araştırmalar. İstanbul Üniversitesi Orman Fakültesi Dergisi, Seri: A, 31(1), 203-216.

Göksin, A. (2001). Kızılçamın Botanik Özellikleri, Kızılçam El Kitabı 2, 13-14.

Gürboy, B. (2007). Kuzey Kıbrıs'ta doğal olarak yetişen kızılçam (Pinus brutia Ten.)'in lif morfolojisi. Süleyman Demirel Üniversitesi Orman Fakültesi Dergisi, Seri A, 2, 119-127.

Hafızoğlu, H., Usta, M. (2005). Chemical composition of coniferous wood species occuring in Turkey. Holz als Roh-und Werkstoff, 63, 83-85.

Hafizoğlu, H., Deniz, İ. (2011). Odun Kimyası Ders Kitab1, Karadeniz Teknik Üniversitesi Orman Fakültesi, Trabzon.

Kayacık, H. (1980). Orman ve park ağaçlarının özel sistematiği, Gymnospermae (Açı Tohumlular), Ístanbul Üniversitesi Orman Fakültesi Dergisi, Cilt I, Yayın No. 281. İstanbul.

Kırc1, H. (1991). Alkali sülfit antrakinon etanol (ASAE) yöntemiyle kızılçam (Pinus brutia Ten.) odunundan kağıt hamuru üretim koşullarının belirlenmesi, Doktora Tezi, Karadeniz Teknik Üniversitesi, Fen Bilimleri Enstitüsü, Trabzon.

Mahesh, S., Kumar, P., Ansari, S. A. (2015). $A$ rapid and economical method for the maceration of wood fibers in Boswellia serrata Roxb., Tropical Plant Research, 2(2), 108-111.
Neyisci, T. (2001). Kızılçam ormanlarında yangindan korunma ve mücadele, Kızılçam El Kitabı 2, 125-131.

Papajoannou, J. (1936). Eine new varietat von Pinus brutia Ten., Pinus brutia Ten. var. agrophyottii. Extrait des Praktika de l'Académie d'Athenes, 11, 14-24.

Praciak, A. (2013). The CABI encyclopedia of forest trees.

Sarıusta, S. E. (2007). Sarıçam (Pinus Sylvestris L.), karaçam (Pinus Nigra Arnold.) ve kızılçam (Pinus brutia Ten.) reaksiyon odununun anatomik yapısı ve kimyasal bilesimi üzerine araştırmalar, Yüksek Lisans Tezi, Zonguldak Karaelmas Üniversitesi Fen Bilimleri Enstitüsü, Zonguldak.

Schiller, G. (2000). Inter-and intra-specific genetic diversity of Pinus halepensis Mill. and P. brutia Ten. In: Ne'eman G. and Trabaud L. (eds), Ecology, Biogeograhy and Management of Pinus halepensis and P. brutia Forest Ecosystems in the Mediterranean Basin, Backhuys Publishers, Leiden, pp.13-35

Selik, M. (1962). Eine neue Varietat von Pinus brutia Ten.(Pinus brutia Ten.var. pyramidalis Selik var.nov.) Sonderdruck aus Mitteilungen der Deutschen Dendrologischer Gesellschaft, Jahrbuck, 1961/62, Nr.2.

Tank, T., Göksel, E., Cengiz, M., Gürboy, B. (1990). Hızlı gelişen bazı iğne yapraklı ağaç türlerinin lif ve kağıt teknolojisi yönünden incelenmesi. İstanbul Üniversitesi Orman Fakültesi Dergisi, 40(1), 40-54.

Tutus, A., Çiçekler, M., Özkan, H. G. (2017). Fireproof paper production from Turkish Red Pine (Pinus brutia Ten.) using fire retardants. Kastamonu University Journal of Forestry Faculty, 17(2), 275-281.

URL-1. Erişim tarihi: 17.10.2017, https://www.mgm.gov.tr/

URL-2. Erişim tarihi: 8.2.2018, http://www.tappi.org/content/Standards\% 20and $\% 20$ Methods/003 Numeric_Index TM.pdf

Yaltırık F. Boydak M. (1989). Ülkemizde yeni bir kızılçam varyetesi. İstanbul Üniversitesi Orman Fakültesi Dergisi, A: 39: 42-64. 
Yaltırık, F., Boydak, M. (2000). A new variety of Calabrian pine (Pinus brutia Ten.) from Anatolia. Karaca Arboretum Magazine (TEMA), 5(5), 173-180.
Yaltırık, F. Efe, A. (2000). Dendroloji Ders Kitab1 (Gymnospermae-Angiospermae), 2.Bask1, Yayın No: 465/4265, İstanbul. 